\title{
THE TRAINING AND DUTIES OF SANITARY INSPECTORS.
}

\author{
By PHILIP BOOBBIER, MID., \\ (FELLOW).
}

\begin{abstract}
ADDRESS TO ANNUAL MEETING OF ASSOCIATES.
\end{abstract}
oN

Tuesda!, March 1.4h, 1905.

70 some of you this may aprear a rery simple theme. It may seem risions of the Public Health Acts, By-liws, Regrulations, and Orders, and of the Memorandum on the subject of an inspector's duties issued by the Local Government Board, together, perhaps, with a short course of practical training, are all that is necessary to qualify any average man for the successful performance of the multifarious duties now devolving upon an inspector of nuisances.

I may say at once, howerer, that anyone who takes this view is not only wofully mistaken, but is likely to be led by his ignorance into errors which a wiser and better informed man would aroid. Fuols, here as elsewhere, rush headlong in, where angels fuar to tread. An under-estimate of difficulties and an over-estimate of one's capacity for dealing with them are just as dangerous to inspector's of nuisances as to military men, although the consequences to others may not wither in character or actuil sum be quite so serious in the first as in the last case.

When we reflect that an inspector, not on s]ecial duty, must be to some extent at least a jack of all trades and professions, that he must know something, and the more the better, of the work of an architect, engineer, builder, plumber, lawyer, medical man, chemist, veterinary surgeon, butcher, provision dealer, and many other tralesmen and professionals too numerous to particularize, we realise at once that, however energetic he may be in the acquisition of knowledge and in the performance of his duties, he can never be safe without a considerable ballast of tact, discre- 
tion, and common sense. It is knowledge of detail, be it ohserved, which a young inspector most lacks and most requires.

Common sense is an essential for all of us if we are to achicre success. This most uncommon of natural qualifications has been defined as a right sense of common things, and let this definition suffice us here, but it signifies to me very much more than this. Those of you who have it will know what I mean, but to those who have not, no amount of explanation would make it plain.

I have not come here to-night to preach a homily, but the influence of an inspector at his best is such a power for good in the community, that $I$ am constrained to linger for a moment upon the moral note. The sanitary inspector is above all things a health missioner, and many things besides simple ardour and zeal are necessary for a successful missionary.

Honesty, sympathy, courtesy, love of our fellows, indomitable patience, energy and courage, a love of work for work's sake, and a devotion to duty are the characteristics of a gentleman. This noblest work of Gorl is found in every clime and in every social gracle. There is no reason why an inspector should not be a gentleman or a gentleman an inspector, and when such a combination occurs (and I am pleased to say I have known it occur pretty often) the advantage to the community in which he labours is wreat and lasting.

We are learning much from the Japanese, now-it-dlays, and those of you who would obtain a faint insight into the moral heart of that great people should read an article on the "Sonl of a Nation," which appeared in the Times on Octoher 4th, 1!nt. The cult of Bushido in Japan has been inalequately translater as that of knightly chivalry. The following is a brief extract from the article I have mentioned:-

"If we cannot adequately express all that Bushiclo is, we can say what it is not. Talie the aremge scheme of life of the average society of the West, and Bushiclo, as nearly as may be, represents its exact antithesis. Bushido offers us the ideal of poverty instead of wealth, humility in place of ostentation, reserve instead of reclame, selt-sacrifice in place of selfishness, the care of the interest of the State rather than that of the individual. Bushiclo inspires ardent courage and the refusal to turn the back upon the enemy; it looks death calmly in the ficce, and prefers it to ignominy of any kind. It preaches submission to autbority, and the sacrifice of all private interests, whether of self or of family, to the common weal. It rerquires its disciples to submit to a strict physical and mental discipline, develops a martial spirit, and, by lauding the virtues of courage, constance, fortitude, faithfulness, daring, and self-restraint, offers an exalted corle of moral principles, not only for the man and the warrior, but for men and women in times both of peace and of war." 
Remember the words of our own juet, Pope :

"Honour and shame from no rondition rise, Act well thy part, there all the bonour lies."

As I am speaking to Associates of The Royal Sanitary Institute, I shall not refer except incidentally to the qualifying Examination of the Institute or to that of the London Board. I shall surmise that all have passed one of these preliminary tests of fitness.

With this preface, I will now proceed to consider in some detail the official instructions wiven by the Local Government Board to an inspector of nuisances regarding his duties.

In the first place he is told that he must perform the duties assigned to him by the Public IIealth Act, 1875, and other sanitary statutes, and by the Orders of the Local Government Board, either (1) under the special direction of the sanitary anthority, or (2) (if so instructed by the latter) under the directions of the medieal officer of health, or angain (3), where no such directions are required, without such directions.

It is, I think, hardly necessary to point out that a knowledge of sanitary law, so far as it bears upon his duties, is absolutely esscential to the inspector, if only to tell him what his cluties are. The model by-laws, also, arc a valuable stuide to the inspector even when not in force in his district. These by-laws establish a reasonable standard with regard to various matters coming within the inspector's laily cognizance. The scope of the latter must of course vary widlely with the character of his clistrict. In a sparsely inhabited rural area, he will have very different rluties from those falling to him in a city slum.

Again, in an industrial urban district with many workshops and factories, his functions will for the most part be entirely diverse from those in a residential suburb.

The presence or absence of such things as canals, common lodginghouses, dairies and cowsheds, piggeries, pullic abattoirs, private slanghterhouses, and jublic markets, the particular methods of excrement disposal and of general scavenging in use, and a thousand other factors which you can imagine for yourselves by thinking of the characteristics of neighbourhoods you know of throughout the country, will necessarily make the widest possible difference to the work an inspector is called upon to perform.

The differences in an inspector's work occasioned by a diversity of conditions such as I have suggested are indeed so great as sometimes to produce bewilderment and even dismay to a thoughtful and conscientious official of this class at the ontset of his career. 
It should be remembered that there is a considerable difference between the legal powers conferred by public health legislation upon urban and rural anthorities respectively. The distinction, however, between the powers bestowed upon the two classes of districts and authorities is clearly drawn by the Public Health $\Lambda$ cts.

I have said in my remarks on sanitary law that a general knowledge of the scope of lis duties is essential to an inspector, and the inference from my later observations is that a thorough knowledge of his district and its characteristics (viewed from a sanitary stanlpoint) is equally desirable, that he may know in what directions his official energies are likely to find occupation.

Now, with regarl to the knotty question of how far he is to look for special direction from the sanitary authority and the medical ofticer of health, and how far he is to rely upon his own knowledge, cliscretion, and judgment in the performance of his duties. The Locial Government Boird are of ten blamed for speaking so vagnely upon this point, but a moment's consideration of the extraordinary differences between sanitary anthorities and sanitary listricts, and the erpuipment and organization of their health clepartments, will convince any thoughtful person that they could hardly have done otherwise than put the matter as they have. In sume districts the medical officer of health is paid only a small innual retaining fee (perhaps as little as £5 per annum) and is expected to give an opinion only when specially called upon to do su, whereas the inspector is practically left in sole charge, and is paid, and expecterl, to devote his whole time to his duties.

Again, in some districts it is the practice of the local authority to appoint sub-committees to conduct inspections, with or without their officers, while in others such action is disapproved as tantamount to keeping a $\operatorname{dog}$ and doing one's own barking.

A gain, in other districts, like those of our large industrial centres, the IIealth Department is a large and well organized machine with a numerous staff. In such a clistrict the ordinary individual iuspector is simply one personal unit among many, acting (probably in some special capacity) either under the medical officer of health or a chief inspector. These extreme instances will serve to indicate how greatly the inspector's duties and powers of initiative may vary in different places. In whatsoever district, or character of district, you may happen to find yourself, let me alvise you, in the absence of distinct abuses affecting your office, injurious to your own or the public interest, to carry out the duty assigned to you to the best of your ability, without endeavouring to adjust your official 
relations according to your own preconceptions. The inspector has a most important and responsible position to fill and duties to perform, but he is not (usually at least) a scientific expert, and, if he be wise, he will bear this last fact stealfastly in mind. We none of us know too much about the scientific aspect of our work, but remember that it is only by such knowledge that our work can have sure foundation. The Japanese, Americans, and Germans, especially, among our contemporaries, are continually reminding us of the fact that applied science is the safest guide, the surest foundation in this regard. Some inspectors remind me at times of the kite in the poet Cowper's poen, which tried to fly without a string, and came to grief in consequence. It is the rule-of-thumb practice of sanitary inspection in the past which has brought so much reproach upon the inspector's office, and has led people to think and say that anyone was good enough to be an inspector of nuisances.

My advice to you is, that you should not endeavour to run too much alone, at any rate until or unless you are reasonably sure that you are running in the right direction. In some districts I know of (e.g., Birmingham and Edinburgh) medical officers of health have been appointed chief sanitary inspectors, in order to insure that the inspecting staff shall have reliable scientific direction in the jerformance of their duties.

The inspector is directed by the Local Gorernment Board Memorandum to attend all meetings of the local authority when so required. In the case of ordinary inspectors this attendance will be required only on special occasions, except in small districts where the inspector is in a more or less independent position under the local authority.

I know that many inspectors regard the attendance at Committees and Councils as a great privilege, but $I$ can assure you it is often a disadvantage and hindrance, both to the inspector and to his work. A man is quite as likely to make enemies as friends on the Committees by coming into close contact with the memlers, and his work under such circumstances will often be interfered with, whereas in his absence it would be passed and approved without comment.

I have alrearly spoken of the necessity for the inspector to malic systematic and regular inspection of the district or section of work for which he is appointed. This inspection will not only keep him informed upon rarious matters (nuisances and the like) over which he has supervision, but also, if he act wisely, establish him in the public respect, and exert a moral influence upon potential offenders against Public Health Acts, regulations, orders, and by-laws. His influence will be malogous to that of a police patrol in a disorderly neighbourhood. 
The inspector's reports to the sanitary authority should be in writing or type-written, should he brief, definite, and to the point. His recommendations should be clearly stated, and in all important matters he should endeavour to secure their entry on the minutes. This is desirable as a personal safeguard for the insprector in case of a public inquiry into local sanitary administration.

Continuing our review of the Local Gorernment Board Memorandum, we find that instructions are given to the ordinary inspector regarding his duties: (1) when notified of the existence of a nuisance, or of the breach of any by-laws or regulations made by the sanitary authority for the suppression of nuisances; (2) in dealing with offensive trades and breaches of by-laws and regulations made in respect of such trades; (3) in safeguarding works of water-supply, and preventing fouling and waste; (4) in the inspection of food-stuffs intenderl for the food of man, sold or exposed for sale (P.H.A.A. Acts), and the seizure, condemnation, and destruction of such as appear to him and the Merlical Officer of Health and a Justice of the Peace to be unfit for sucll use; (5) in the taking and submitting for analysis samples of food, drink, and drugs under the Sale of Food and Drugs Acts. Now, we have here set out only a part of the special functions which may devolve upon a single inspector, although most sanitary authorities who take themsclves seriously lave come to realize the necessity of appointing more than one officer where there is any considerable amount of work to be done under these numerous headings.

In order to remind you once more of the varions functions of the inspectorial staff in a large city, I will now enumerate the principal inspectors employed in a large and well organized urban health department in the provinces. Here we hare-

1. The district inspectors of nuisances, say 1 inspector to each 40,000 inhabitants (see sec. 91, Public Health Act, 1875);

2. The meat and provisions and slaughterhouse inspectors (sec. 116, Public Health Act, 1875):

3. The local workshop (and, to some extent, factury) inspectors (Factory and Workshops Act, 1901) and shop hours act inspectors (Shop Hours Act);

4. The canal boats inspector (Canal Boats Act, 1877, and Regulations, 1878);

5. The common lodging-house inspector and inspector of houses let in lodgings (secs. 76-80, Public Health Act, 1875, and sec. 90, modified by sec. 8 , Housing of the Working Classes Act, 1885); 
6. The inspector or inspectors under the Sale of Food and Drugs Acts, with unofficial assistants (Sale of Food and Drugs Acts, 1899);

7. The infectious diseases inspectors, with disinfecting staff (sec. 120 and onward, Public Health Act, 1875, and Infectious Diseases Prevention Act) ;

8. The health visitors appointed usually as inspectors of nuisances, but serving in a new capacity as school and home visitors among the poor.

I have excluded from this list such offices as those of petroleum, hackney-carriage, and market inspectors, because they are more commonly under a police than a sanitary committee in large towns at least.

The Memorandum goes on to instruct the inspector that he must promptly notify the medical officer of health of any cases of epidemic disease which may come to his knowledge, and also take his direction for the measures of prevention to be adopted.

Next we come (in the Local Gorernment Board Memorandum) to the official instruction as to the keeping of a cliary and other books, constituting a continuous record of inspections made, of work done, and of the condition of premises in respect of which it has been undertaken. The books kept in a well-organized health department are very numerous, and a useful knowledge of these can only be acquired by a careful study of the books themselves. The most important are :-

Nuisance books, letter books, note books, and files.

Infectious diseases registers (one for each disease).

Common lodging-house register.

Canal boats register.

Workshops register.

Outworkers register.

Slaughiterliouse and knackers' yards registers.

Offensive trades register.

Dairies, cowsheds, and milkshops register.

Margarine makers register.

The Local Government Board Memoranlum next requires that the inspector shall at all reasonable times produce, on recuest, to the medical officer of health, all or any of his books, and give him besides any information at his disposal relating to matters coming within the scope of the inspector's duties. 'This requires no comment. The two officers could not work together without some such provision.

Next, he is instructed, if so required by the sanitary authority, to superintend the due execution of all works undertaken by their direction for the abatement of nuisances. Notice the proviso "if so required." 
Now, if the inspector is without architectural or engineering training he is clearly incompetent to undertake the supervision of works of construction appertaining to either of these professions, and it is far better for him and for all parties that he should have associated with him a person who has had such training to supervise the work undertaken in obedience to his (the inspector's) notice. In small districts, and especially in rural districts, the offices of surveyor and inspector are of ten combined in one appointment, hut usually in large urban districts either a qualified surveyor is appointed in the health department to undertake such supervision, or the latter is left to an officer in the town surveror's department.

The question of the supervision of the work carried out under notice from the inspector has given rise to a great deal of discussion in different places from time to time, but I think the above is a fair general solution.

The next section of the Memorandum instructs the inspector, when so required by the sanitary authority, to act as their officer under the Contagious Diseases (Animals) Act, and its orders and regulations. I have had some experience of the working of this Act and the orders and regnlations made under it, and am of opinion that their administration is best undertaken by the police, aided by a veterinary surgeon; and this, I believe, is also the view of the Board of Agriculture. Many inspectors are required for this work, and every policeman on duty can be called upon, if necessiry, to act as an inspector for this special purpose.

The Memorandum concludes with an order to the inspector to do the lawful bidding of the sanitary authority and the Local Government Board in other matters, not here set down lut appertaining to his office.

So much for the duties of an inspector after appointment. Let us nuw consider briefly how he mar best qualify himself for their performance by training and instruction acquired beforehand.

Under existing conditions it is a very difficult thing for an inspector to obtain any useful amount of training before appointment. The regulations of The Royal Sanitary Institute require that every candidate for its diploma shall have obtained a certain amount of practical insight into the office and outside work of a sanitary inspector, before presenting limself for examination: the London Sanitary Inspectors' Examination Board, moreover, demands that he shall have held for three years prior to 1900 the post of sanitary inspector in a simitary listrict of the United Kingdom having a population of not less than 5,000 inhabitants, or have attended thirty-two systematic lectures with demonstrations. But no one seriously thinks that either of these courses, except perhaps the first condition of the London Boarl, is sufficient to give the candidate an effective 
grasp of his duties in practice. When one reflects as we have this erening upon the grave responsibilities frequently devolving upon the office of inspector, and then considers the amount of preparation which the average inspector undergoes before appointment, one is immerliately struck with the extreme inadequacy of this preparation. Many remedies have been suggested, but none is quite satisfactory. The crux of the whole matter is want of means on the part of most of the candidates to cuable them to support themselves cluring the necessary period of preparation. It is, of course, out of the question that with the comparatively small reward in the way of salary which an inspector candidate has to look forward to, that he should devote so long a period to study and preparation as, say, a doctor, an engineer, an architect, or a lawyer, before earning a living wage. But I would suggest the general adoption of a plan which, theoretically at least, is unobjectionable. I refer to a system of apprenticeship, assistantship, and subsequent promotion. An apprentice can be employed at a small salary as a general inspectorial understudy in the district, and the length of his tether should be increased with the growth of his capacity for ruming alone. In most trades and professions this system is adopted for the education of their youthful members, and it usually works exceedingly well. There are, of course, practical difficulties in the way of the general adoption of it for sanitary inspectors. It will, for instance, often be difficult to find room for hegimners in well-equipped health departments, except on the distinct understanding that they must look elsewhere for permanent employment; but, once adopted, the plan works well, for men who have served as assistants for some time in a well-known and well-equipped district have less difficulty in obtaining a permanent appointment than candidates without such recommendation.

I have purposely avoided non-esiential details in my address to-night, because I have only one adciress to deliver and much gencral ground to cover, but I must say a few words upon the subject of after-study for an inspector. Never be ashamed to learn. Finowledge brings power, comfort, courage, and advancement. Whatever you are most deticient in, endeavour to work up by private study, by attendance at evening classes and lectures, and other means of instruction available. Keep your eyes and ears open when going your rounds, and endeavour to note and look up things you do not understand. Industry and a conscientious and intelligent sense of duty will bring their own reward, for if by doing your duty to the best of your ability you do not achicve as much material success as you deserve, you will at least have the confort of knowing that you have done for others 
and $f_{(1)}$ yourself the best that lay in your power, and this knowledge, accorling to one of omr greatest philusophers, is the highest reward of such noljle action.

Now just a few words in conchusion upon the much-discussed question of how far provincial officers are liable to suffer, under existing conditions, for the impartial performance of their duty. Of course, we all desire fixity of tenure, and, what is more to the point, we are going to have it before long. But I wish you to know that, in my experience (extending over more than twonty years), a couscientions officer, whether inspector or medical ofticer of health, is much less likely to suffer for the diligent and straightforwarr performine of his duty than from its neglect. I could tell you of many instances in which officers have been almost universallyrespected and well rewarded for the efficient and impartial discharge of necessary but umpleasant duty, but I know of very few indeed where they have suffererl loss from this cause. 